Short Communication

\title{
Environmental Assessment of Central European Floodplain Forests: A Case Study from the Morava River Alluvium
}

\author{
Jarmila Filippovová1, Tomáš Pohanka ${ }^{2 *}$ \\ ${ }^{1}$ Palacky University, Faculty of Science, Department of Development and Environmental Studies, \\ Olomouc, Czech Republic \\ ${ }^{2}$ Palacky University, Faculty of Science, Department of Geoinformatics, Olomouc, Czech Republic
}

Received: 17 July 2018

Accepted: 10 September 2018

\begin{abstract}
Areas subject to little anthropogenic impact and with preserved river dynamics are very rare in the floodplains of large European rivers [7-9]. These environmentally valuable territories are usually categorized as different forms of protected areas. Particularly due to the establishment of the Natura 2000 network of nature protection areas, the number of floodplain forests thus protected in Europe has been gradually increasing. In the context of environmental assessment of Natura 2000 sites, environmental assessment of the level of natural habitat conservation appears to be a potential decision support tool. This paper assesses the efficiency of the Natura 2000 European Network in the biodiversity conservation of Central European floodplain forest habitats on the ecosystem level of an entire river basin (Morava River basin, Czech Republic). In order to express the efficiency of natural habitat conservation, our paper uses the nature conservation efficiency index, which is calculated in the GIS environment based on an environmental analysis of data obtained through natural habitat mapping in the Czech Republic, conducted in 2001-2004 as part of the conservation objectives of Natura 2000. Environmental analysis results show that the conservation efficiency of the Natura 2000 network in territorial conservation of floodplain forests in the study area of the Morava River floodplain is approximately six times as high $(\mathrm{NCEIEU}=0.067)$ as the efficiency of the Czech national network of protected areas $(\mathrm{NCEICZ}=0.017)$. The paper also highlights the importance of detailed habitat mapping for environmental landscape studies.
\end{abstract}

Keywords: assessment; floodplain forest; habitat conservation; spatial analyses

$\overline{\text { *e-mail: tomas.pohanka@upol.cz }}$ 


\section{Introduction}

The environmental impact of climate change on the floodplains of large European rivers can be seen in an increased risk of floods to human settlements [1, 2]. European cultural landscapes along the lower reaches of large rivers were considerably changed due to long-term anthropogenic use in the past [3, 4]. Today, the lower reaches of large European rivers are technically adjusted and have lost their natural fluvial dynamics $[5,6]$. The remaining areas with preserved river dynamics and with little anthropogenic impact are very rarely found in the floodplains of large European rivers [7-9]. Such environmentally valuable areas are usually protected under different categories of protected areas [10], the most valuable being included in the Natura 2000 European network $[11,12]$. The fluvial river dynamics in these places create a unique gradient of floodplain forest beta-diversity [13]. The gradient encompasses a varied mosaic of succession series of fluvial habitats ranging from the initial stages of willow stands on fresh gravelsand river sediments to richly structured hardwood floodplain forest stands [14, 15].

Some of the protected areas of European floodplain forests are potentially under the threat of large investment development projects, e.g., the Danube-Oder-Elbe waterway project of an inland canal connecting three large European rivers [16]. Such investment projects are subjected to environmental impact assessment [17] which, among other things, assesses the impacts of such projects on Natura 2000 sites [18]. Environmental evaluation of the value and degree of natural habitat protection appears to be a potential decision support tool for the environmental assessments of Natura 2000 sites [19]. The importance of environmental evaluation of habitats becomes more pronounced in the context of raising environmental awareness about ecosystem services [20]. The need for an environmental assessment of ecosystem services is proportional to the degree of anthropogenic use of the landscape [21, 22]. An environmental assessment of natural habitats in the landscape can be optimally implemented through the so-called ecosystem approach at the level of self-contained river basins, which represent clearly defined landscape ecosystems [23].

Biodiversity is essential for the existence and function of most ecosystem services [24]. Conservation of ecosystem biodiversity therefore conditions the functioning of ecosystem services at the landscape level $[25,26]$. Environmental assessments of the efficiency of biodiversity protection through protected areas thus yield key information for each complex environmental assessment of the landscape [27].

The importance of floodplain forests as secluded refugia of unique biodiversity in European cultural landscapes has motivated the establishment of different systems and categories of protected areas. The number of such protected areas of floodplain forests in Europe has been gradually increasing, namely in the context of the Natura 2000 network of protected areas. However, what is the efficiency of these protected areas (PAs) in conserving the biodiversity of European floodplain forests?

The forum of environmental publications is dominated by discussions concerning the actual efficiency of protected areas and the factors that affect it [28]. Starting with the end of World War 2, the issue was tackled by efforts to achieve a representativeness of the national network of protected areas that would ideally encompass each rarely occurring type of habitat. However, these efforts had failed until the late $20^{\text {th }}$ century. Under the communist regime PAs covered large territories, but their protection and management regime resembled those of "paper parks." PAs were not given real protection until after the changes in the political regime in 1992, following a new Act on Nature and Landscape Protection. As part of the EU accession process, complex habitat mapping was conducted on the territory of the entire country in 2001-2004. Its results were applied in the establishment of a network of protected areas of the Special Areas of Conservation category within Natura 2000.

This paper aims to assess the efficiency of the Natura 2000 European network in the biodiversity conservation of Central European floodplain forest natural habitats at the ecosystem level of an entire river basin (Morava River basin, Czech Republic). It highlights the potential of natural habitat mapping in the environmental assessment of landscapes.

\section{Experimental}

\section{Study Area}

The studied area encompasses the alluvial landscape along the Morava River in the Czech Republic (CR). The border of the study area was defined based on geological maps of 1:50,000 [29]. It is formed by the boundary of the Quaternary fluvial sediments of the Morava River [30].

The Morava is a left tributary of the Danube, a large and important European river. The Morava originates on Mt. Kralicky Sneznik [31] near the state border between $\mathrm{CR}$ and Poland and has a vaguely southward trajectory. The lower reach of the river's course forms the border between CR and Slovakia and then between Austria and Slovakia (Fig. 1). The length of the Morava from its source to the confluence with the Dyje River at the state border is about $270 \mathrm{~km}$. The Morava feeds the Danube in Slovakia by an average discharge rate of $120 \mathrm{~m}^{3} \cdot \mathrm{s}^{-1}$, gathered from a drainage area of $26,658 \mathrm{~km}^{2}$. The Morava floodplain is only a few meters wide in the upper mountain reaches and widens gradually towards the south along the river up to a width of several kilometres. The surface area of the studied floodplain was $635.7 \mathrm{~km}^{2}$ and the elevation ranged from 900 to $151 \mathrm{~m}$ a.s.l. 


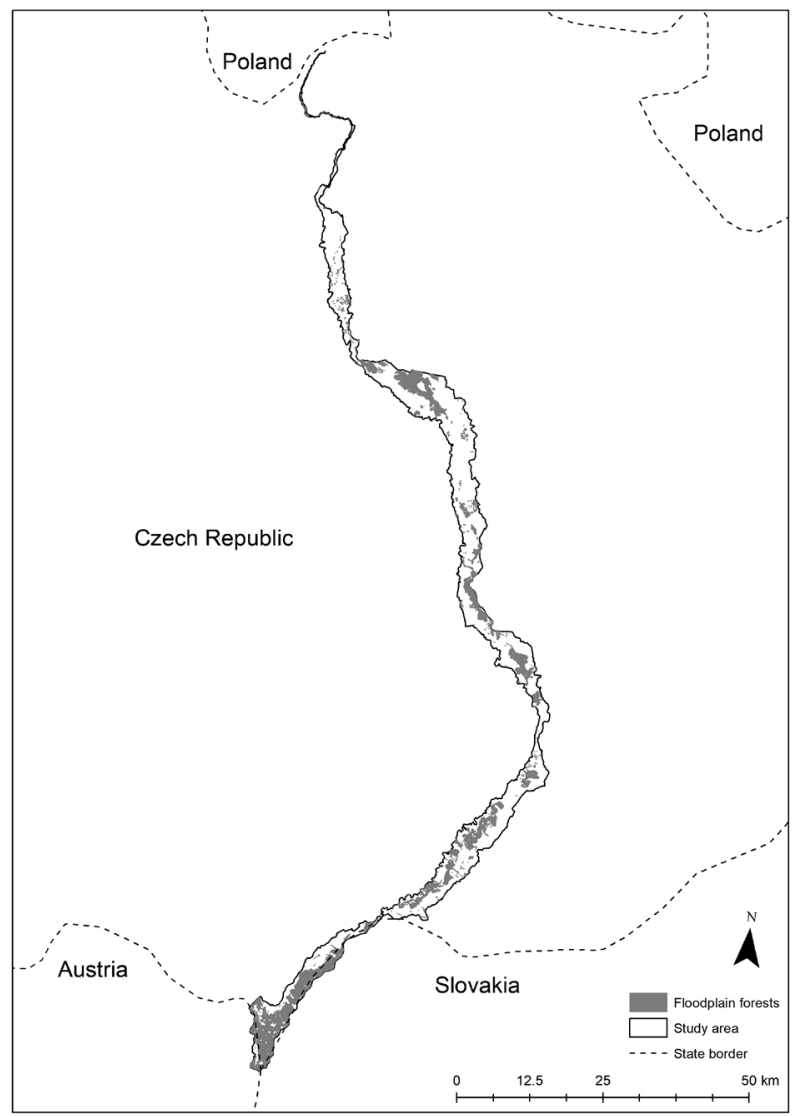

Fig. 1. Study area.

Long-term average annual perception in the Morava watershed is $670 \mathrm{~mm}$. Locally, in higher areas, could be yearly average perception of almost $1000 \mathrm{~mm}$. Long-term annual average temperature is $8.1^{\circ} \mathrm{C}$. The coldest month is January, with long-term yearly average temperature $-2.6^{\circ} \mathrm{C}$ and the hottest month is July at $17.7^{\circ} \mathrm{C}$.

Morava watershed has an area of 997430.07 ha. The significant proportion of soil groups are Cambisol (48.71\%), Fluvisol (14.97\%), Luvisol (11.45\%) and Chernozem (9.78\%). The rest of the groups (15.09\%) contain Pozdol, Phaeozem, Regosol, Gleysol or Planosol. Cities occupy $0.3 \%$ of the total area [32]. According to CORINE LC 2012 data, agriculture and forests hold $56.04 \%$ and $36.89 \%$ (42.84\% coniferous tree), respectively.

\section{Method of Conservation Efficiency Calculation}

The method is based on the results obtained from the mapping of natural habitat distribution in the Czech Republic conducted in 2001-2004 within the conservation aims of the so-called Habitat Directive (Council Directive 92/43EEC on the Conservation of Natural Habitats and of Wild Fauna and Flora). The natural habitats are described in the Catalogue of Habitats of the Czech Republic [33] (hereinafter referred to as the "Catalogue").
To express the conservation efficiency of natural habitats, our paper uses the nature conservation efficiency index (NCEI) [34]. A modification of this index, $\mathrm{NCEI}_{\mathrm{CZ}}$, was applied to assess the efficiency of the Czech national network of protected landscape areas in the conservation of natural floodplain forest habitats, calculated for each specific natural habitat from the following equation:

$$
\mathrm{NCEI}_{\mathrm{CZ}}=\mathrm{TANH}_{\mathrm{NPA}} / \mathrm{TANH}_{\mathrm{C}}
$$

Where $\mathrm{TANH}_{\mathrm{CZ}}$ represents the total area of a habitat type in the Czech Republic and $\mathrm{TANH}_{\mathrm{NPA}}$ represents the total area of a natural habitat in the national network of protected areas in the country.

To assess the efficiency of the European network of protected areas in CR (i.e., the SAC network within Natura 2000) in the conservation of natural floodplain forest habitats, a modified index $\mathrm{NCEI}_{\mathrm{EU}}$ was applied, calculated for every specific habitat using the following equation:

$$
\mathrm{NCEI}_{\mathrm{EU}}=\mathrm{TANH}_{\mathrm{SAC}} / \mathrm{TANH}_{\mathrm{CZ}}
$$

...where $\mathrm{TANH}_{\mathrm{CZ}}$ represents the total area of a habitat in the country and $\mathrm{TANH}_{\mathrm{SAC}}$ is the total area of a natural habitat in the Special Areas of Conservation (SAC) within the Natura 2000 network in the Czech Republic.

The dimensionless values of the NCEI index can range from 1 (totally efficient conservation) to 0 (absence of conservation). The calculated value NCEI $>0.75$ indicates highly efficient conservation (over three quarters of the total area of all identified natural habitats are protected within protected areas), NCEI values ranging from $0.74-0.50$ indicate moderately efficient conservation (more than half of the given natural habitat is included in protected areas), and $\mathrm{NCEI} \leq 0.49$ indicates low conservation efficiency (less than half of a natural habitat's total area is covered by protected areas).

To determine the NCEI index, two digital datasets were used, both managed by the Agency for Nature Conservation and Landscape Protection of the Czech Republic: (1) biotope mapping layer and (2) SAC boundaries layer. All data processing was conducted in ArcGIS 10.4, the data were processed in the vector format (Esri geodatabase) and the coordinate reference system for the Czech Republic (epsg: 5514).

\section{Results and Discussion}

\section{Assessed Habitat Types}

A total of eight habitat types were identified through mapping for the purposes of floodplain forest habitat assessment in the study area. In the natural conditions of the Czech Republic, all these habitat types are considered a set of habitats constituting 


\begin{tabular}{|c|c|c|c|c|c|c|c|c|}
\hline 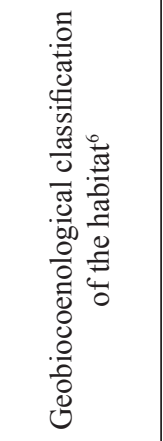 & 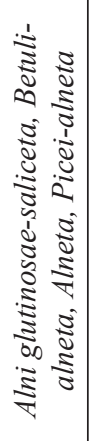 & 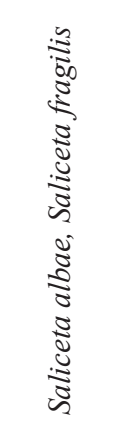 & 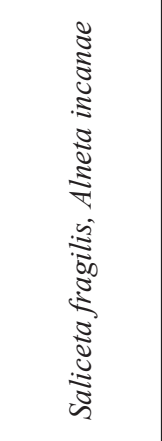 & 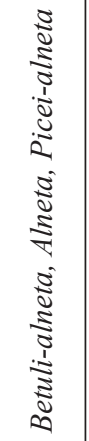 & 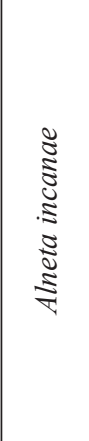 & 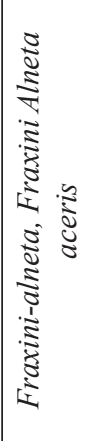 & 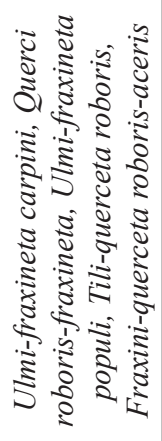 & 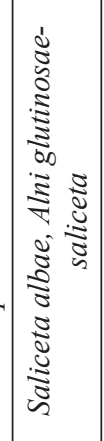 \\
\hline 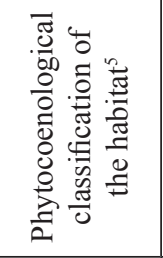 & 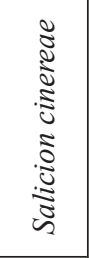 & 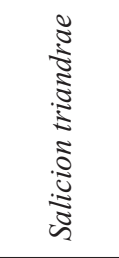 & 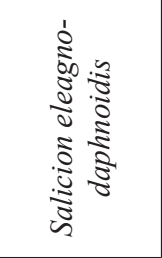 & 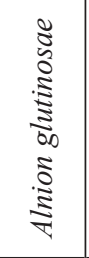 & 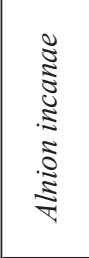 & 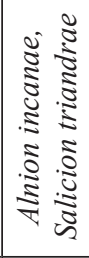 & 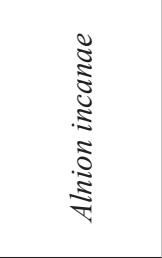 & $: \Sigma \bar{\Xi}$ \\
\hline 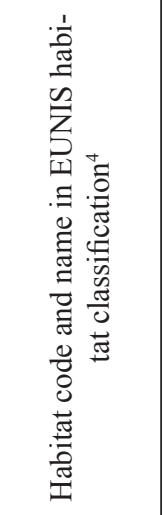 & 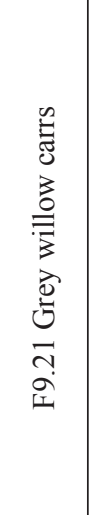 & 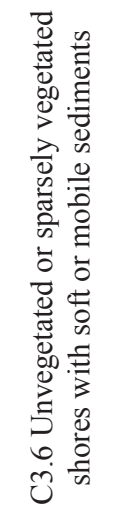 & 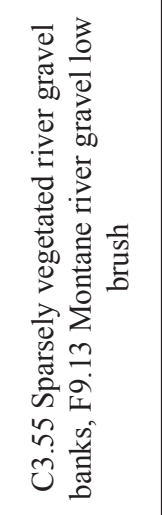 & 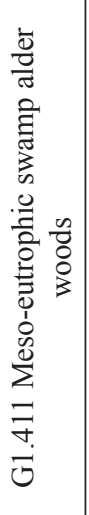 & 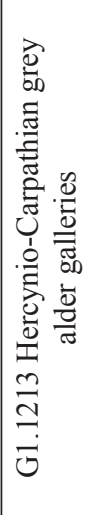 & 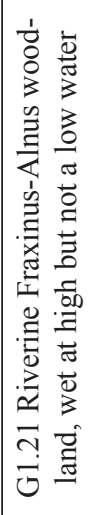 & 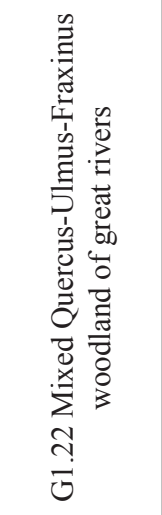 & 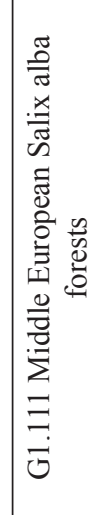 \\
\hline 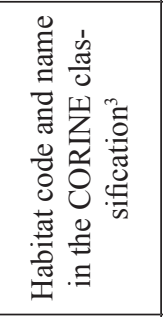 & 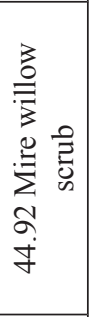 & 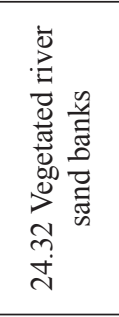 & 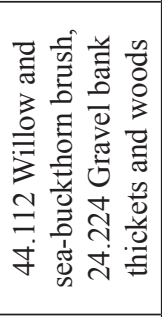 & 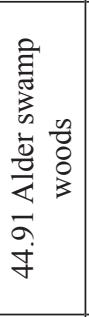 & 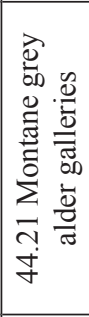 & 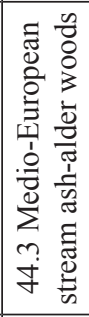 & 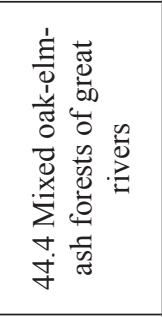 & $\vec{f}$ \\
\hline 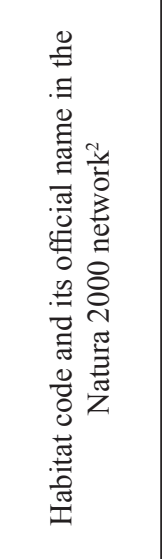 & & ' & 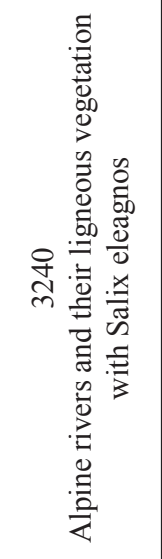 & & 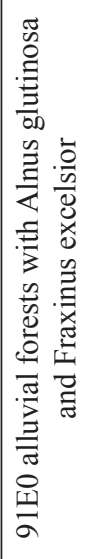 & 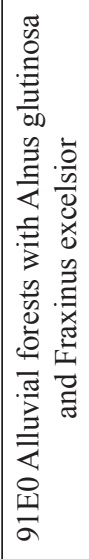 & 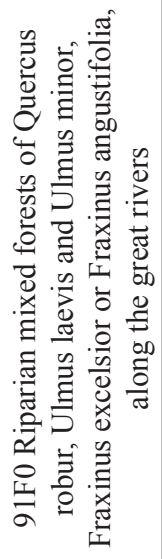 & 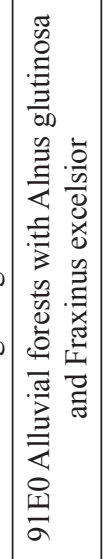 \\
\hline 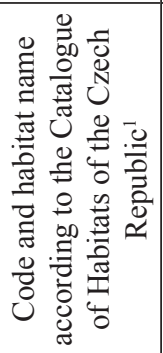 & 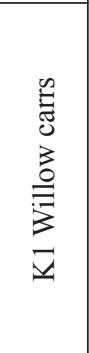 & 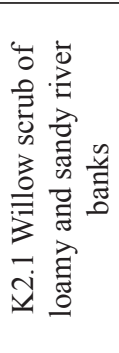 & 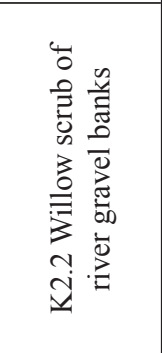 & 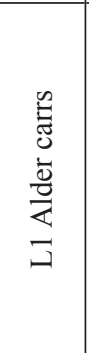 & 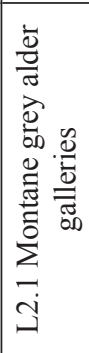 & 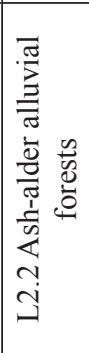 & 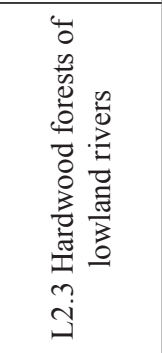 & 8 \\
\hline
\end{tabular}


Table 2. Conservation efficiency of natural floodplain forest habitats in the Morava River alluvium.

\begin{tabular}{|c|c|c|c|}
\hline \multicolumn{2}{|c|}{$\begin{array}{c}\text { Area of floodplain forest natural habitats [ha] } \\
\text { Czech Republic }\end{array}$} & $\begin{array}{c}\text { Percentage share of the } \\
\text { total area of habitats } \\
\text { in CR }\end{array}$ & NCEI Index \\
\hline Morava River alluvium & 155520 & 100 & -- \\
\hline Special Protection Areas & 7799.6 & 7.7 & 0.05 \\
\hline Special Areas of Conservation & 9940.5 & 5.0 & 0.064 \\
\hline Together in the Natura 2000 European Network * & 10484.4 & 6.4 & NCEI $_{\mathrm{EU}}=0.067$ \\
\hline Large-scale protected areas & 2074.6 & 6.7 & 0.013 \\
\hline Small-scale protected areas & 1437.1 & 1.3 & 0.9 \\
\hline Together in the Czech national network of protected areas* & 2619.6 & 1.7 & NCEI $_{\mathrm{CZ}}=0.017$ \\
\hline
\end{tabular}

* after subtracting overlays

an environmentally interconnected succession series of habitats.

The Czech national network of protected areas encompasses a total of 2,619.6 hectares of natural floodplain forest habitats in the study area of the Morava River alluvium, which represents a mere $1.7 \%$ of the total area of all types of natural habitats of floodplain forests mapped in the Czech Republic (Table 2). The table clearly reveals the system weakness of the Czech national network of protected areas (both large-scale and small-scale) when it comes to floodplain forest conservation - a very low conservation efficiency in these environmentally highly valuable natural habitats $(\mathrm{NCEICZ}=0.017)$.

The floodplain forest conservation efficiency of the European network of protected areas (Natura 2000) in the Morava River alluvium study area (10,484.4 ha), on the other hand, is much higher: NCEIEU index $(0.067)$ is approximately six times as high as NCEICZ (Table 2).

Floodplain forests of the European temperate climate zone consist of broadleaved deciduous forests in the wide river alluvia of large lowland rivers and gallery forest vegetation along streams and mountain creeks [35]. Anthropogenic activities in the past (e.g., forest grazing) also have had a major impact on the present character of floodplain forests [36]. After all, the most valuable floodplain forest nature reserves in the Czech Republic, famous for their mighty ancient oaks, are in fact historical remnants of grazing forests [37]. At present, ungulate browsing poses a major threat to some European floodplain forests, preventing natural generative propagation of trees due to the absence of large carnivore predators in some sites and thus changing the biodiversity of mapped forest habitats [38].

The present state of floodplain forest ecosystems has been significantly affected by forest management. The first reports generally describing the status of riparian forests along tributaries of the river Morava appeared in 1723 (Židlochovice manor). The first forest management plans were created at the end of the 18th and at the beginning of the 19th centuries [39]. The original methods of floodplain forest management, based on coppice-with-standards silvicultural system, were replaced by high forest cultivation in the late 19th century [40]. Yet coppice-with-standards management survived locally in European floodplain forests until the mid-20th century. Relics of former coppices within floodplain forests, the so-called ancient forests [41], represent cultural and historical monuments of high biological value. Floodplain forest management in some valuable floodplain forest regions in Europe (e.g., in Croatia) has been traditionally built on pedunculate oak (Quercus robur L.) natural regeneration, which is an exemplary model of forest management striving to retain oak dominance in forest stands. This is important both economically and biologically, as oak constitutes the key species in floodplain forest biodiversity [42].

Despite that, flood activity in middle Morava culminated largely in 1821-1840, 1891-1920, 19311950 and 1961-1980. Flood frequency decreased significantly in 1991-2009, although, paradoxically enough, the most disastrous flood occurred in this period (July 1997) [43]. Recent years are bound to arouse interest in the ecosystem functions of floodplain forests in the landscape. This is already manifested in major restoration projects implemented in floodplain forests. In the Czech Republic, the Programme for the Restoration of River Systems is aimed at restoring disturbed areas of floodplains. Most such projects have been implemented in accordance with the principles of ecological restoration [44].

Environmental assessment of the conservation efficiency of protected areas is viewed as an important aspect of supporting biodiversity conservation at the landscape level. The emphasis on an ecosystem approach is essential. The presented paper applied the ecosystem approach in the choice of study area, seeing the entire Morava River basin as a geographically and ecologically defined landscape ecosystem. 
Mapping of natural habitats and an environmental assessment of their conservation has become an important support decision tool for policymakers [45]. The results of the presented paper indicate that natural habitat mapping under the Natura 2000 national networks can be well applied in developing methods of floodplain forest biodiversity assessment at the European level. However, this methodology has a shortcoming: the existing differences in national natural habitat mappings in individual EU member states [46]. As results presented in this paper show, the method of conservation efficiency assessment fails as a decision support tool for landscape management in regionally rare habitat types, and as such must be supplemented (particularly in protected areas) with other methodologies applying decision support tools or their combinations [47].

\section{Conclusions}

We can conclude that awareness of the conservation efficiency of protected areas in river catchments based on an ecosystem approach can prove to be an important decision support tool for both the environmental impact assessment and ecosystem management at a landscape level. Although some published studies have pointed out the low efficiency of Natura 2000 European network at a national level [48], the efficiency of floodplain forest conservation through Natura 2000 in the Czech Republic is significantly higher than that of the Czech national network of protected areas.

\section{Acknowledgements}

This study was conducted and funded by financial support of the "Cultural landscape of Olomouc Archdiocese - research, presentation and management" grant as a part of the NAKI II program of the Ministry of Culture of the Czech Republic.

\section{Conflict of Interest}

The authors declare no conflict of interest.

\section{References}

1. KLEMESOVA K., ANDRASKO I. Perception of floods - towards more effective flood management in the Czech Republic. Carpathian Journal of Earth and Environmental Sciences 10 (2), 199, 2015.

2. KOPECKA V., MACHAR I., BUCEK A. AND KOPECKY A. The Impact of Climate Changes on Sugar Beet Growing Conditions in the Czech Republic. Listy Cukrovarnicke a Reparske 129, 326-, 2013.

3. PECHANEC V., BURIAN J., KILIANOVA H., NEMCOVA Z. Geospatial Analysis of the Spatial
Conflicts of Flood Hazard in Urban Planning. Moravian Geographical Reports 19 (1), 41, 2011.

4. MACHAR I. Changes in ecological stability and biodiversity in a floodplain landscape. In Applying Landscape Ecology in Conservation and Management of the Floodplain Forests. Machar, I., Ed., Palacky University: Olomouc, Czech republic., 73, 2012.

5. MIRIJOVSKY J., BRUS J., Pechanec V. Utilization of a small-format aerial photography from drone pixy concept in the evaluation of the landscape changes. In $11^{\text {th }}$ International Multidisciplinary Scientific Geoconference SGEM. STEF92: Sofia, II, 345, 2011.

6. KILIANOVA H., PECHANEC, V., SVOBODOVA J., MACHAR I. Analysis of the evolution of the floodplain forests in the alluvium of the Morava River. In 12th International Multidisciplinary Scientific GeoConferenceSGEM. STEF92: Sofia, 1, 2012.

7. KLASZ G., RECKENDORFER W., GABRIEL H., BAUMGARTNER C., SCHMALFUSS R., GUTKNECHT D. Natural levee formation along a large and regulated river: The Danube in the National Park Donau-Auen, Austria. Geomorphology 215, 20, 2014.

8. MACHAR I. Conservation and Management of Floodplain Forests in the Protected Landscape Area Litovelske Pomoravi (Czech Republic). Palacky University: Olomouc, 7, 2009.

9. PECHANEC V., MACHAR I., POHANKA T., OPRSAL Z., PETROVIC F., SVAJdA J., SALEK L., CHOBOT K., FILIPPOVOVA J., CUDLIN P., MALKOVA J. Effectiveness of Natura 2000 system for habitat types protection: A case study from the Czech Republic. Nature Conservation - Bulgaria 24, 21, 2018.

10. OPRSAL Z., HARMACEK J., PAVLIK P., MACHAR I. What Factors can Influence the Expansion of Protected Areas around the World in the Context of International Environmental and Development Goals? Problemy Ekorozwoju, 13 (1), 145, 2018.

11. MIKO L. Nature and landscape protection in the European context. In Ochrana Prirody a Krajiny v Ceske Republice. Machar, I.,Drobilova, L.,,Eds, Palacky University: Olomouc, Czech republic, I-II, 439, 2012 [In Czech].

12. MACHAR I., SIMON J., REJSEK K., PECHANEC V., BRUS J., KILIANOVA H. Assessment of Forest Management in Protected Areas Based on Multidisciplinary Research. Forests, 7 (11), 285, 2016.

13. SCHNITZLER-LENOBLE A. Forêts alluviales d'Europe. Lavoisier, Paris, 1, 2007.

14. SIMON J., MACHAR I., BUCEK A. Linking the historical research with the growth simulation model of hardwood floodplain forests. Polish Journal of Ecology, 62 (2), 273, 2017.

15. SALEKL L., SIVACIOGLU A., TOPACOGLU O., ZAHRADNILE D., JERABKOVAL L., MACHAR I. Crowns of Old Remnant Oak Standards. Fresenius Environmental Bulletin 26 (6), 4023, 2017.

16. MACHAR I., KIRCHNER K., PECHANEC V., BRUS J., KILIANOVA H., SALEK L., BUCEK A. Potential geo-ecological impacts of the proposed Danube-OderElbe Canal on alluvial landscapes in the Czech Republic. Moravian Geographical Reports, 23 (2), 38, 2015.

17. FISCHER T.B. The Theory and Practice of Strategic Environmental Assessment. Earthscan: London, 1, 2017.

18. MÖCKEL S. The European ecological network "Natura 2000" and the appropriate assessment for projects and plans under Article 6 (3) of the Habitats Directive. Nature Conservation - Bulgaria, 23, 1, 2017. 
19. PECHANEC V., MACHAR I., STERBOVA L., PROKOPOVA M., KILIANOVA H., CHOBOT K., CUDLIN P. Monetary Valuation of Natural Forest Habitats in Protected Areas. Forests 8 (11), 427, 2017.

20. WUNDER S. When payments for environmental services will work for conservation. Conservation Letters, 6, 230, 2013.

21. PARKS S., GOWDY J. What have economists learned about valuing nature? A review essay. Ecosystem Services, 3, 1, 2013.

22. FERRARO P.J. The Future of Payments for Ecosystem Services. Conservation Biology 25, 1134, 2011.

23. KILIANOVA H., PECHANEC V., BRUS J., KIRCHNER K., MACHAR I. Analysis of the development of land use in the Morava River floodplain, with special emphasis on the landscape matrix. Moravian Geographical Reports, 25 (1), 46, 2017.

24. GARCÍA-AMADO L.R., PEREZ M.R., GARCIA S.B. Motivation for conservation: Assessing integrated conservation and development projects and payments for environmental services in La Sepultura Biosphere Reserve, Chiapas, Mexico. Ecological Economics, 89, 92, 2013.

25. PECHANEC V., BRUS J., KILIANOVA H., MACHAR I. Decision support tool for the evaluation of landscapes. Ecological Informatics, 30, 305, 2015.

26. FARLEY J., COSTANZA R. Payments for ecosystem services: From local to global. Ecological Economics, 69, 2060, 2010.

27. PECHANEC V., CUDLIN P., STERBOVA L., MACHAR I. Biodiversity as an ecosystem service: A case study from the Olomouc Archdiocese area (Czech Republic). In $16^{\text {th }}$ International Multidisciplinary Scientific Geoconference-SGEM 2016. STEF92: Sofia, 113, 2016.

28. MACHAR I. Protection of nature and landscapes in the Czech Republic Selected current issues and possibilities of their solution. In Ochrana Prirody a Krajiny v Ceske Republice. Machar I., Drobilova L., Eds, Palacky University: Olomouc, Czech republic, I-II, 91, 2012. [In Czech].

29. MACKA Z. Geology, Geomorphology and Human Impact over the Fluvial System. In History, Biodiversity, and Management of Floodplain Forest (Case Study of National Nature Reserve of Vrapac, Czech Republic), Machar I., Ed., Palacky University: Olomouc, Czech republic. 27, 2009.

30. LECHOWSKA E. The Impact of Embankment Construction on Floodplain Land Use in the Context of its Influence on the Environment: a Case Study of Selected Cities in Poland. Polish Journal of Environmental Studies, 26 (2), 655, 2017.

31. KOVARIK P., KUTAL M., MACHAR I. Sheep and wolves: Is the occurrence of large predators a limiting factor for sheep grazing in the Czech Carpathians? Journal for Nature Conservation, 22 (5), 479, 2014.

32. KOLEKTIV, 2009. Plánu oblasti povodí Moravy 2010-2015. Brno: Povodí Moravy, s.p., 2009 [In Czech].

33. CHYTRY M., KUCERA T., KOCI M., GRULICH V., LUSTYK P. Katalog biotopu Ceske republiky AOPK CR: Praha, Czech republic, 1, 2010 [In Czech].

34. PENKA M., VYSKOT M., KLIMO E., VASICEK F. Floodplain Forest Ecosystem II. After Water Management Measures. Academia: Praha, 1, 1991.

35. KLIMO E., HAGER H. The floodplain forests in Europe: Current situation and perspectives. European Forest
Institute Research Report no. 10. Koninklijke Brill NV, Leiden, 1, 2001.

36. MACHAR I., ANTONIN V., CERMAK P., HORCICKO I., HRADILEK Z., JANKOVSKY L., JOHN F., KOSTKAN V., KULHAVY J., KURFURST P., LACINA J., MACKA Z., MERTA L., MRKVA R., SANKA M., SIMON J., VAGNER A. History, Biodiversity, and Management of Floodplain Forest (Case Study of National Nature Reserve of Vrapac, Czech Republic). Palacky University: Olomouc, 1, 2009.

37. BARANCEKOVA M., KROJEROVA-PROKESOVA J., HOMOLKA M. Impact of deer browsing on natural and artificial regeneration in floodplain forest. Folia Zoologica, 56 (4), 354, 2007.

38. CERMAK P., HORSAK P., SPIRIK M., MRKVA R. Relationships between browsing damage and woody species dominance. Journal of Forest Science (Prague), 55, 23, 2009.

39. NOŽIČKA J. Přehled vývoje našich lesů. SZN: Praha, Czech republic, 1, 1957 [In Czech].

40. SZYMURA T. How does recent vegetation reflects previous system of forest management? Polish Journal of Ecology, 60 (4), 859, 2012.

41. BUCEK A., CERNUSAKOVA L., FRIEDL M., MACHALA M., MADERA P. Ancient coppice woodlands in the landscape of the Czech Republic. European Countryside, 9, 617, 2017.

42. JOHNSON P.S., SHIFLEY S.R., ROGERS R. The Ecology and Silviculture of Oaks. SABI Publishing: New York, 1, 2002.

43. BRAZDIL R., ŘEZNÍČKOVÁ L., VALÁŠEK H., HAVLÍČEK M., DOBROVOLNÝ P., KOUKALOVÁ E., ŘEHÁNEK T., SKOKANOVÁ H. Fluctuations of floods of the River Morava (Czech Republic) in 1691-2009 period: interactions of natural and anthropogenic factors Hydrological Science, 56 (3), 468, 2011.

44. MACHAR I. Attempt to summarize the problems: Is a sustainable management of floodplain forest geobiocenoses possible? In Biodiversity and target management of floodplain forests in the Morava River basin (Czech Republic). Machar I., Ed., Palacky University: Olomouc, Czech Republic, 189, 2010.

45. MAES J., EGOH B., WILLEMEN L., LIQUETE C., VIHERVAARA P., SCHÄGNER J.P., GRIZETTI B., DRAKOU E.G., LA NOTTE A., ZULIAN G. Mapping ecosystem services for policy support and decision making in the European Union. Ecosystem Services, 1, 31, 2012.

46. APOSTOLOPOULOU E., PANTIS J.D. Conceptual gaps in the national strategy for the implementation of the European Natura 2000 conservation policy in Greece. Biological Conservation, 142, 221, 2009.

47. MACHAR I., VOZENILEK V., SIMON J., PECHANEC V., BRUS J., FULNECEK P., VITEK T. Joining of the historical research and future prediction as a support tool for the assessment of management strategy for European beech-dominated forests in protected areas. Nature Conservation - Bulgaria 22, 51, 2017.

48. DE KONING J., WINKEL G., SOTIROV M., BLONDET M., BORRAS L., FERRANTI F., GEITZENAUER M. Natura 2000 and climate change - Polarisation, uncertainty, and pragmatism in discources on forest conservation and management in Europe. Environmental Science and Policy, 39, 129, 2014. 